\title{
Alterocupar-se: obliquação e transicionalidade na experiência literária
}

\author{
Alterocupar-se: obliquation and transitionality \\ in literary experience \\ Alterocuparse: oblicuación y transicionalidad \\ en la experiencia literaria
}

Alexandre Nodari*

\section{Resumo}

O artigo busca desenvolver a noção de obliquação e entender por que a experiência literária parece ser o seu lugar privilegiado, por meio de um movimento duplo, mas conjugado. Em primeiro lugar, trata-se de pensar, através de uma leitura transversal da teoria da enunciação, a obliquação como condição fundamental da reflexividade - que seria, para fazer uso de um jogo de palavras, um reflexo à obliquação. Assim, se em seu curso sobre A hermenêutica do sujeito, Foucault se propunha realizar "uma analítica das formas da reflexividade, na medida em que são elas que constituem o sujeito como tal", a nosso ver, tal exercício ainda precisa ser complementado por uma ontologia dos modos de obliquação, entre os quais está a experiência literária aqui analisada. Em segundo, levando isso ao paroxismo, tentaremos argumentar, fazendo um livre uso do conceito de objetos transicionais, que a obliquação precede e até mesmo possibilita a ocupação do próprio lugar, ou seja, de que há um privilégio ontológico da ficção, do outrar-se, sobre a própria subjetividade.

Palavras-chave: obliquação, transicionalidade, experiência literária.

\section{Abstract}

This article aims at developing the notion of obliquation, as well as understanding why literary experience seems to be its place of privilege, by means of a double, albeit conjoined, movement. First, it is a matter of thinking of obliquation, through a transversal reading of the theory of enunciation, as a fundamental condition of reflexivity. Therefore, if in his course on The Hermeneutics of the Subject, Foucault proposes an "analytics of the forms of reflexivity, inasmuch as it is the forms of reflexivity that constitute the subject as such," in our opinion, such an exercise still needs to be complemented by an ontology of the modes of obliquation, including the literary experience analyzed here. Second, elevating the oblique to a paroxysm, we will try to argue, making free use of the concept of transitional objects, that obliquity precedes and even enables the occupation of one's own place, i.e., that there is an ontological privilege of fiction, of othering, over one's own subjectivity.

Keywords: obliquation, transitionality, literary experience.

\section{Resumen}

El artículo intenta desarrollar el concepto de oblicuación y comprehender la experiencia literaria como su locus privilegiado, a través de un duplo movimiento conjugado. En primer lugar, trátase de pensar por intermedio de una lectura transversal de la teoría de la enunciación, la oblicuación como condición fundamental de la reflexividad - la cual sería, para jugar con las palabras, un reflejo à la oblicuación. Así, si en su curso sobre la hermenéutica del sujeto, Foucault se proponía realizar "una analítica de las formas de la reflexividad, en la medida en que son éstas las que constituyen al sujeto como tal", para nosotros, este ejercicio necesita complementarse con una ontología de los modos de oblicuación, entre los cuales está el de la experiencia literaria aquí analizada. En segundo lugar, llevando eso al paroxismo, intentaremos argumentar, haciéndo un uso libre del concepto de objetos transicionales, que la oblicuación precede y hasta posibilita la ocupación del propio hogar, o sea, de que hay un privilegio ontológico de la ficción, de hacerese otro sobre la propia subjetividad.

Palabras clave: oblicuación, transicionalidad,

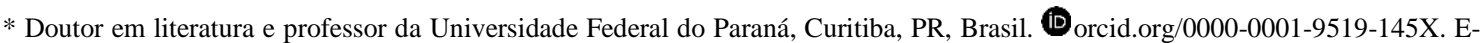
mail: alexandre.nodari@gmail.com.
} 
experiencia literaria.

\author{
O lugar onde eu nasci nasceu-me \\ num interstício de marfim, \\ entre a clareza do início \\ e a celeuma do fim. \\ Eu jamais soube ler: meu olhar \\ de errata a penas deslinda as feias \\ fauces dos grifos e se refrata: \\ onde se lê leia-se. \\ Eu não sou quem escreve, \\ mas sim o que escrevo: \\ Algures Alguém \\ são ecos do enlevo.
}

Décio Pignatari

"[E]ntre mim e eu"

\begin{abstract}
A barata com a matéria branca me olhava. Não sei se ela me via, não sei o que uma barata vê. Mas ela e eu nos olhávamos, $e$ também não sei o que uma mulher vê. Mas se seus olhos não me viam, a existência dela me existia - no mundo primário onde eu entrara, os seres existem os outros como modo de se verem. E nesse mundo que eu estava conhecendo, há vários modos que significam ver: um olhar o outro sem vê-lo, um possuir o outro, um comer o outro, um apenas estar num canto e o outro também estar ali: tudo isso também significa ver. A barata não me via diretamente, ela estava comigo. A barata não me via com os olhos mas com o corpo.
\end{abstract}

Clarice Lispector, A paixão segundo G.H.

Partindo de um trecho de Água viva, de Clarice Lispector (1998, p. 63) - "estou percebendo uma realidade enviesada. Vista por um corte oblíquo" -, bem como do particular encavalgamento pronominal presente na sua escritura em formulações como "A vida se me é", "Eu não sou Tu, mas mim és Tu" (Lispector, 1997, p. 115, 85), sugeri chamar de obliquação um movimento complexo de desdobramento subjetivo e das posições enunciativas, cuja face mais visível se apresenta quando o sujeito, sem deixar completamente de sê-lo, ocupa também a posição de objeto. Enquanto modo de, linguisticamente, tomar a si mesmo como objeto, o pronome oblíquo da primeira pessoa do singular ("mim") pareceu-me um bom índice para nomear essa relação transversal, de terceira margem entre o eu e o outro, na medida em que seu uso implica, mesmo que implicitamente, também o do "eu": trata-se de uma espécie de paralaxe perspectiva-pronominal, a saber, ver como um sujeito - dizer "eu" $-e$ ver-se (portanto, como objeto) da perspectiva de outro (eu) - referir-se a si como "mim". ${ }^{1}$ Isso implica dizer que o movimento que constitui a obliquação não se reduz ao simples gesto de referir-se a si mesmo como objeto ou ainda à reflexividade: para tomar-me como objeto, preciso admitir a existência da (e ocupar a) posição de um outro sujeito. ${ }^{2}$

\footnotetext{
${ }^{1}$ Embora possa haver uma diferença entre ponto de vista e posição enunciativa, que está sendo explorada por André Goldfeder e Roberto Zular e que pode ter implicações importantes para a noção de obliquação e seu funcionamento (em especial, na literatura), estamos postulando a sua equivalência para nossos propósitos aqui, afinal, "há vários modos que significam ver". Sobre uma possível sinonímia conceitual, seria interessante investigar se e como o perspectivismo (em especial, de Ortega y Gasset) configura uma condição de possibilidade da teoria da enunciação de Benveniste - relação que está na base, diga-se de passagem, da formulação do perspectivismo ameríndio por Eduardo Viveiros de Castro, como se pode ver já no (título do) seminal ensaio, "Os pronomes cosmológicos e o perspectivismo ameríndio", bem como nas leituras que ele faz seja do diálogo cerimonial na antropofagia ritual tupi, seja do mote do encontro sobrenatural na mata.

${ }^{2}$ É essa simultaneidade de posições, em tese contraditórias, que se enuncia na famosa formulação de Ortega y Gasset, "yo soy yo y mi circunstancia": eu enquanto conjunto eu+mundo, e eu enquanto parte (objeto) desse conjunto, podendo ser reescrita como "eu sou minha circunstância, da qual eu sou uma das partes". Retomando o seu perspectivismo, segundo o qual cada eu traz consigo um mundo (eu-e-minha-circunstância), composto de inúmeros objetos-para-o-sujeito, entre os quais pode emergir (pelo menos) um outro eu, um "alter ego", para quem eu sou um objeto-de-seu-mundo, poderíamos dizer que a posição oblíqua marcaria justamente
} 
Nesse sentido, pode ser esclarecedor retornar à outra fonte da noção de obliquação, a "Introdução à obra de Marcel Mauss". Ali, Lévi-Strauss (2003) aborda a dificuldade inerente às ciências humanas, na medida em que o objeto de conhecimento delas é, ao mesmo tempo, um sujeito (outros povos). Para dar conta desse objeto que é um sujeito, é preciso que o sujeito da investigação se "objetive" como um outro sujeito e veja o mundo e a si mesmo com os olhos deste, que veja a si mesmo como um outro - como um objeto. Trata-se, portanto, de ser ao mesmo tempo como sujeito e objeto, e um objeto de tipo peculiar, que também é um sujeito. A obliquação assim entendida consiste em um movimento que comporta quatro posições que se equivocam (pois todas agem ao mesmo tempo e em um mesmo corpo): i) ver o outro (um objeto que é um sujeito); ii) ver a si mesmo como objeto (ver a si mesmo como um sujeito outro, sendo outro); iii) ver como o outro sujeito; e iv) ver a si mesmo como o outro (sujeito) o vê. Não seria este o movimento em jogo também na experiência literária? Diante dos "egos experimentais", como Milan Kundera (2009) chamou os personagens de ficção e que servem de índice para tudo que fala num texto literário, não precisaríamos (leitores e escritores) passar por um experimento do ego, que consiste em subjetivar o outro objetivando a si? O próprio Lévi-Strauss parece aproximar a objetivação de si a um exercício de ficção (do "como se"), quando apresenta a sua condição de possibilidade: "[a]s milhares de sociedades que existem ou existiram na superfície da terra são humanas e, por essa razão, delas participamos de forma subjetiva: poderíamos ter nascido nelas, e podemos portanto buscar compreendê-las como se nelas tivéssemos nascido" (2003, p. 27, grifos nossos). Todavia, não estaria o argumento invertido? Ou seja, será que podemos obliquarmo-nos, ocupando a posição de outros sujeitos ao mesmo tempo que a nossa, apenas porque temos algo substancialmente em comum com eles, ou será que, ao contrário, só podemos travar uma interlocução com a alteridade porque somos capazes de nos obliquarmos (ficcionalizarmos)? A segunda alternativa parece ser a que Elizabeth Costello apresenta quando define como fonte da "imaginação simpatética" (o que Lévi-Strauss chamaria de "objetivação de si") a possibilidade de "pensar minha via de adentrar a existência de um ser que nunca existiu", ou seja, a ficção. E se isto é possível, se é possível adentrar a existência de um ser que nunca existiu, então, conclui a personagem de Coetzee (2004, p. 92, tradução modificada), também é possível "pensar minha via de adentrar a existência de um morcego ou um chimpanzé ou uma ostra, de qualquer ser que participe comigo do substrato da vida", incluindo, mas não se restringindo a, outros humanos, demasiado humanos. Nosso intuito aqui é radicalizar essa posição, colocando a seguinte questão: o que essa experiência implica para o sujeito, e para a definição e a estrutura ontológica que subjaz a ele?

\section{Eu, pronome oblíquo}

Ser o eu mesmo significaria, pois, ser capaz de se duplicar.

Wolfgang Iser, O fictício e o imaginário

"As duas primeiras pessoas do singular não servem de condição à enunciação literária", diz Deleuze (1997, p. 13) numa famosa passagem: "a literatura só começa quando nasce em nós uma terceira pessoa que nos destitui do poder de dizer Eu", o que "parece desmentir", acrescenta em nota, "a concepção linguística que encontra nos embreantes, e especialmente nas duas primeiras pessoas, a própria condição da enunciação". O seu alvo é, evidentemente, Benveniste (1995, p. 288), para quem, como se sabe, a subjetividade se funda na/pela linguagem, mais especificamente na enunciação, "que permite a cada locutor apropriar-se da

um ponto de sobreposição (ou sobredeterminação) entre esses dois mundos e subjetividades: de um ponto de vista ontológico, o pronome "mim" designa, ao mesmo tempo, o eu-enquanto-sujeito-de-seu-mundo e o eu-enquanto-objeto-do-mundo-de-outro. Se, para o outro, eu sou um "ele", um "isso", e vice-versa, então "mim" marca tanto a minha posição-para-o-outro, a de objeto de seu mundo, de outro mundo, quanto a minha posição de sujeito do meu próprio mundo (na medida em que, como vimos, seu uso linguístico implica também o do pronome reto "eu"): a obliquação sou eu vendo/sendo visto de dois pontos de vista distintos e incompatíveis, o próprio e o do outro, o que torciona essas posições ao limite (ou para além dele), tornando impossível determinar e individuar um sujeito e um objeto unívocos. 
língua toda designando-se como $e u^{\prime \prime} .^{3} \mathrm{Na}$ raiz dessa operação, porém, encontramos uma dobradura ou torção do sujeito, pois se "eu é o 'indivíduo que enuncia a presente instância de discurso que contém a instância linguística eu", então há na enunciação, como aponta o próprio Benveniste (1995, p. 279), "uma dupla instância conjugada: instância de eu como referente, e instância de discurso contendo eu, como referido". Dizer eu implica, assim, desdobrar-se em referente e referido, eu-enunciador e eu-enunciado, sujeito e objeto, ego e id, primeira e terceira pessoa, e também linguagem e mundo, ${ }^{4}$ ou seja, obliquar-se em polos ou posições que a descrição do aparelho formal da enunciação por Benveniste busca fazer coincidir no seu grau zero, o "colocar em funcionamento a língua por um ato individual de utilização" (Benveniste, 2006, p. 82). É a produção dessa co-incidência no (dizer) "eu” que faz deste uma instância sui-reflexiva, que faz do sujeito que enuncia a si mesmo (objeto) o centro de referência, o ponto zero do eixo espaço-temporal, do mundo, fornecendo-lhe "o sentimento de uma continuidade que denominamos 'tempo'" (Benveniste, 2006, p. 85-86). Todavia, se é necessária uma conjugação, isso implica que há originariamente duplicidade. É como se a co-incidência mascarasse o caráter de máscara da pessoa (persona), a natureza prosopopeica (prosopon poiein: produzir pessoas/máscaras), ou seja, poética, da subjetividade, o aspecto de encenação de toda enunciação: todo cuidado de si envolve tomar-se como personagem de si mesmo, toda coincidência se ampara numa equivocidade.

\section{Ecos}

'Médium', assim, de mim mesmo, todavia subsisto.

Fernando Pessoa

Isso fica mais explícito no monólogo, quando o "EGO ou se divide em dois, ou assume dois papéis" (Benveniste, 2006, p. 88), em que a terceira pessoa "interna" - o "eu" referido - se subjetiva, convertendo-se em uma segunda ou mesmo primeira pessoa (um "tu" ou um "eu"), dialogando e mesmo trocando de posição com o "eu" referente. O monólogo é classificado por Benveniste (2006, p. 87-88),

não obstante a aparência, como uma variedade do diálogo, estrutura fundamental. [...] O "monólogo" é um diálogo interiorizado, formulado em "linguagem interior", entre um eu locutor e um eu ouvinte. Às vezes, o eu locutor é o único a falar; o eu ouvinte permanece, entretanto, presente; sua presença é necessária e suficiente para tornar significante a enunciação do eu locutor. Às vezes, também, o eu ouvinte intervém com uma questão, uma dúvida, um insulto.

Se devemos falar em uma "transposição do diálogo em 'monólogo'", "facultada pelo aparelho linguístico da enunciação" (Benveniste, 2006, p. 88, grifo nosso), é porque dizer "eu" implica um "tu", aquele a quem se enuncia: "A consciência de si mesmo", continua Benveniste (1995, p. 286),

só é possível se experimentada por contraste. Eu não emprego eu a não ser dirigindo-me a alguém, que será na minha alocução um tu. Essa condição de diálogo é que é constitutiva da pessoa, pois implica em reciprocidade - que eu me torne tu na alocução daquele que por sua

\footnotetext{
3 'É na linguagem e pela linguagem que o homem se constitui como sujeito; porque só a linguagem fundamenta na realidade, na sua realidade que é a do ser, o conceito de 'ego'. // A 'subjetividade' de que tratamos aqui é a capacidade do locutor para se propor como 'sujeito'. Define-se não pelo sentimento que cada um experimenta de ser ele mesmo (esse sentimento, na medida em que podemos considerá-lo, não é mais que um reflexo) mas como a unidade psíquica que transcende a totalidade das experiências vividas que reúne, e que assegura a permanência da consciência. Ora, essa 'subjetividade', quer a apresentemos em fenomenologia ou em psicologia, como quisermos, não é mais que a emergência no ser de uma propriedade fundamental da linguagem. É ‘ego' que diz ego. Encontramos aí o fundamento da 'subjetividade' que se determina pelo status linguístico da 'pessoa'” (Benveniste, 1995, p. 286).

${ }^{4}$ A enunciação é o ter lugar da linguagem no mundo: "A realidade à qual ele ["eu"] remete é a realidade do discurso. [...] A instalação da 'subjetividade' na linguagem cria na linguagem e, acreditamos, igualmente fora da linguagem, a categoria da pessoa" (Benveniste, 1995, p.288, 290; grifo nosso). E constitui também o ter lugar do mundo na linguagem: "O ato individual de apropriação da língua [a enunciação] introduz aquele que fala em sua fala [...] [O] homem não dispõe de nenhum outro meio de viver o 'agora' e de torná-lo atual senão realizando-o pela inserção do discurso no mundo" (Benveniste, 2006, p. 84-85).
} 
vez se designa por eu. [...] A linguagem só é possível porque cada locutor se apresenta como sujeito, remetendo a ele mesmo como eu no seu discurso. Por isso, eu propõe outra pessoa, aquela que, sendo embora exterior a "mim", torna-se o meu eco - ao qual digo tu e que me diz tu. A polaridade das pessoas é na linguagem a condição fundamental, cujo processo de comunicação, de que partimos, é apenas uma consequência totalmente pragmática.

A situação dialógica, da interlocução, precede o dizer; a intersubjetividade é anterior à subjetividade. Por isso, em certo sentido, o eu também é um eco do tu, o que pode ser melhor argumentado se invocarmos uma das Últimas aulas de Benveniste (2014, p. 132). Ali, ele aborda a mesma "linguagem interior", caracterizando-a como "rápida, incoerente, pois sempre se compreende a si mesmo", "uma linguagem situada, em um contexto presente, que faz parte da condição da linguagem, inteligível para o falante e apenas para ele", e coloca a questão da passagem desse monólogo (interno) ao diálogo (externo):

Porém, transferir essa linguagem interior - condicionada pela relação do locutor consigo mesmo em uma experiência e uma circunstância única, mutáveis - em uma forma inteligível a outros, e que perde [...] toda relação natural com a ocasião que foi a da linguagem interior, é uma tarefa considerável [...]. Tornar inteligível a linguagem interior é uma operação de conversão que acompanha a elaboração da fala e a aquisição da escrita (Benveniste, 2014, p. 132, grifos do autor).

Desse modo, na medida em que o monólogo é uma variante do diálogo, a cadeia enunciativa completa envolveria, portanto, um jogo complexo de conversões, ou transposições, numa mão dupla de exteriorizações e interiorizações, que poderíamos exemplificar com um esquema simples e simplificador: para enunciar, externalizar sua "linguagem interior", converter seu monólogo em um diálogo a um interlocutor, o "eu” deve re-situá-lo, recontextualizá-lo; por sua vez, o interlocutor, o "tu", converterá essa enunciação em "linguagem interior", em um diálogo consigo mesmo, recontextualizando-o para dentro; sua resposta implicará uma nova externalização e transposição, que, por fim, será internalizada pelo primeiro "eu", fechando a cadeia e colocando a questão se, de fato, a primeira linguagem interior já não teria sido uma internalização ou recontextualização de uma linguagem "externa", movimento que indetermina o que veio antes, a linguagem interior ou a enunciação falada, o dentro ou o fora, o monólogo ou o diálogo, o ego ou o eco. A enunciação é uma caixa de ressonância de ecos - e de egos. ${ }^{5}$

\title{
It: "o mistério do impessoal"
}

\begin{abstract}
$\mathrm{Nu}$, como preparado para a entrada de uma só pessoa. E quem entrasse se transformaria num 'ela' ou num 'ele'. Eu era aquela a quem o quarto chamava de 'ela'. Ali entrara um eu a que o quarto dera uma dimensão de ela. Como se eu fosse também o outro lado do cubo, o lado que não se vê porque se está vendo de frente.
\end{abstract}

Clarice Lispector, A paixão segundo G.H.

Na medida em que dizer "eu" envolve um processo de referenciação, a equivocidade que está na base da enunciação e da subjetividade só pode ser plenamente compreendida se atentarmos a esse terceiro termo, fora da posição subjetiva, exterior à posição de pessoa, a

\footnotetext{
${ }^{5}$ Todavia é preciso sublinhar que, para Benveniste (1995, p. 286-287), a alternância ou alteridade posicionais jamais se converte em equivocidade, pois só um pode ocupar a posição de "eu" a cada vez: a "polaridade não significa igualdade nem simetria: ego tem sempre uma posição de transcendência quanto a tu; apesar disso, nenhum dos dois termos se concebe sem o outro; são complementares, mas segundo uma oposição 'interior/exterior', e ao mesmo tempo são reversíveis". Como comenta Roberto Esposito (2007, p. 128-129), “[o] tu, desse ponto de vista, pressupõe o eu. É o seu alter ego - outro, mas relacionado ao ego que o declara tal desdobrando-se, ou redobrando-se, na própria alteridade. É por isso que o eu não pode deixar de exercitar um efeito de padronização sobre ela, por mais que queira respeitar-lhe em sua autonomia, salvaguardar-lhe em sua transcendência, na medida em que essa alteridade é logicamente dependente dele para sua definição. O que significa, de fato, a alteridade, se não um ponto de contraste em relação à entidade que a precede? [...] A partir do momento que só um - aquele que se refere a si dizendo eu - pode ocupá-la [a posição de sujeito], à subjetivação do primeiro termo corresponde automaticamente a dessubjetivação do segundo, até que este adquira por sua vez subjetividade dessubjetivando o primeiro”. Só pode haver Um.
} 
referência. Nela, talvez a alternância da posição subjetiva dê lugar a uma sobreposição (ou sobredeterminação): "na enunciação, a língua se acha empregada para a expressão de uma certa relação com o mundo. A condição mesma dessa mobilização e dessa apropriação da língua é, para o locutor [eu], a necessidade de referir pelo discurso, e, para o outro [tu], a possibilidade de co-referir identicamente, no consenso pragmático que faz de cada locutor um co-locutor. A referência é parte integrante da enunciação" (Benveniste, 2006, p. 84, grifo nosso). É vicariamente, no lugar de qualquer referência ou nome ou objeto, ${ }^{6}$ que se usa a terceira pessoa, heterogênea às duas primeiras a ponto de ser, em realidade, a "não-pessoa" que permite abrir a enunciação para fora de si: "a não-pessoa é o único modo de enunciação possível para as instâncias de discurso que não devam remeter a elas mesmas, mas predicam o processo de não importa quem ou não importa o que, exceto a própria instância" (Benveniste, 1995, p. 282). Todavia, não seria esse "consenso", a bem da verdade, a obliteração de um dissenso de base, como não cessou de mostrar a desconstrução? Ou então: não seria o seu caráter "pragmático" em realidade uma longa, lenta e impositiva batalha pela univocização?

Aqui, vale lembrar o sentido que dois dos principais termos que usamos para o terceiro excluído da interlocução - "coisa", no vocabulário cotidiano, "res", no jargão filosófico - possuíam no direito romano, em que eram sinônimos da causa de um litígio jurídico. A coisa, a res, antes de indicar um objeto tangível ou intangível, era o nome dado à própria disputa, à própria lide, ao próprio dissenso ou desacordo. Ou seja, causa e res nomeavam uma relação equívoca entre sujeitos:

O sentido primitivo de res oscila entre a lide judiciária e o objeto que a motiva. [...] O vocabulário do procedimento [jurídico] arcaico é extremamente rico em lemas que significam ao mesmo tempo a disputa e a coisa disputada, a controvérsia e o seu objeto. [...] Nas fórmulas mais antigas do direito arcaico, "a coisa de que se trata" [aquilo de que trata uma controvérsia jurídica] era uma "coisa" justamente na medida em que era disputada em um processo. No processo, res [...] se dizia do objeto da disputa, também essa chamada de res (Thomas, 2014, p. 68-70).

O objetivo do processo consistia, assim, em determinar e delimitar a disputa, objetivando- $a$, de modo a permitir a sua decisão pelo magistrado: "O processo como res captura, contém, retalha e modela os seus objetos como res" (Thomas, 2014, p. 72). Não seria possível postular uma analogia e pensar que a referência linguística também é a objetivação de uma relação intersubjetiva pautada pelo desencontro referencial (Felman, 2003)? Nesse sentido, não seria a terceira pessoa um entre-sujeito equívoco, a objetivação da intersubjetividade, e de sua troca posicional - uma relação, um ponto de contato entre mundos? E mais, não seria essa equivocidade constitutiva da referenciação, o "desencontro leve entre as coisas, [em que] elas quase se chocam, [...] desencontro entre os seres que se perdem uns aos outros entre palavras que quase não dizem mais nada", a condição mesma de toda interlocução, pois "quase nos entendemos nesse leve desencontro" (Lispector, 1998, p. 64)? A univocidade ou a identidade do co-referir viriam, assim, a posteriori, para tentar desfazer o litígio e produzir uniformidade (os processos e magistrados que decidem a causa, individuando-a em um objeto; os aparatos institucionais-educacionais que padronizam a língua; a pragmática cotidiana da fala). Parafraseando Gabriel Tarde (2007, p. 98), a co-incidência seria apenas um caso raro e extremo da equivocação - o caso "maior", no sentido deleuzoguattariano, a saber, o padrão, a medida que tenta enquadrar as demais -, assim como o monólogo constitui, como vimos, apenas uma variante do diálogo.

Em certo uso coloquial que fazemos de "coisa", termos análogos e mesmo pronomes da terceira pessoa, encontramos essa mesma sobredeterminação referencial: "Você está uma coisa hoje", "Fulano tem it". É como se o "objeto" assim chamado excedesse a si mesmo ou qualquer nomeação disponível, extrapolasse uma uniformidade designativa ou de substância, marcando que o que está ali não se deixa referenciar univocamente. Nessa "coisidade" atribuída a sujeitos ou objetos, parece, assim, estar implicada a postulação de que estamos diante de algo que é mais que um (ou menos que Um, que não se fecha numa

\footnotetext{
6 “as formas como ele, o, isso, etc. só servem na qualidade de substitutos abreviativos [...]; substituem um ou outro dos elementos materiais do enunciado ou revezam com ele" (Benveniste, 1995, p. 282).
} 
unidade), que está atravessado por outro-que-si (e que pode, como nas formulações românticas e mágicas, aparecer enquanto força impessoal, como a do gênio), como se as coisas em jogo fossem "elementos de um diálogo, simultaneamente relacionadas a si e a outrem" (Lévi-Strauss, 2003, p. 41). Trata-se do que Lévi-Strauss (2003, p. 39), a partir de sua releitura da noção de mana, chamou de "significantes excedentes", e que operam:

um pouco como símbolos algébricos, para representar um valor indeterminado de significação [...], cuja única função é [...] assinalar o fato de que em tal circunstância, em tal ocasião, ou em tal de suas manifestações, uma relação de inadequação se estabelece entre significante e significado.

Nesse sentido, poderíamos arriscar dizer que a terceira pessoa, enquanto único modo de enunciação possível de "não importa quem ou não importa o que, exceto a própria instância", seja o índice, o dêitico de tal excesso/inadequação de significação - da equivocidade - que toda referenciação comporta: ele/ela/isso serviriam, como os significantes excedentes de LéviStrauss, para "opor-se à ausência de significação, sem comportar por si mesm[os] nenhuma significação particular" (Lévi-Strauss, 2003, p. 44). Se estivermos corretos, não poderíamos dizer que é esse excesso/inadequação/equivocidade referencial, enquanto "garantia de toda arte, toda poesia, toda invenção mítica e estética" (Lévi-Strauss, 2003, p. 43), aquilo que a literatura mobiliza e libera? Em uma formulação precisa, Derrida definiu a relação literária com a referencialidade como sendo não da ordem da abolição, e sim da suspensão, uma relação ambivalente que, sem se desprender de todo da referência, também não se limita a ela: "Não há literatura sem uma relação suspensa com o sentido e com a referência. Suspensa quer dizer suspensão, mas também dependência, condição, condicionalidade. Em sua condição suspensa, a literatura apenas pode exceder a si mesma" (Derrida, 2014, p. 70). Ou seja, a referência, em literatura, não deixa de operar, mas agora não coincide mais plenamente consigo mesma, remetendo também a outra coisa, em aberto; marca a si mesma, mas também a sua inadequação, a sua abertura indeterminada a outros sentidos - a referência se converte no acesso a uma floresta densa de correspondências, na qual a relação entre palavras e coisas pode ser rearranjada. Desse modo, reescrevendo a definição em nossos termos, diríamos que a suspensão da referência em jogo na literatura deve ser entendida como suspensão da univocidade referencial e liberação da equivocidade constitutiva: liberta-se, assim, a relação entre palavras e coisas, e a linguagem toda tende à deiticidade.

Para evitar recair em uma oposição simplista e teleológica, podemos acompanhar uma hipótese aventada por Gregory Bateson ${ }^{7}$ e postular que não há propriamente um solo primeiro da equivocidade ao qual se segue a univocidade, mas que primeiro, para dizê-lo paradoxalmente, é a suspensão referencial, a qual constitui tanto o caminho para a coreferenciação idêntica pelo consenso pragmático quanto a vereda que dá acesso ao excedente de significação. Embora pareça contrassensual afirmar que a suspensão da referência preceda o referenciar, é esse, em certo sentido, o argumento que Bateson formula ao observar macacos brincando de combate, uma cena na qual, em um nível pré-verbal e prédenotativo, age um componente de metacomunicação ou metalinguagem que serve para suspender a denotação ainda inoperante: "a mordiscada lúdica [dos macacos] denota a mordida, mas não denota o que seria denotado por ela", ou seja, traz consigo a mensagem metalinguística de que "isto é um jogo", de que "[e]ssas ações que estamos realizando agora não denotam aquilo que seria denotado por aquelas ações que essas ações denotam" (Bateson, 2000, p. 180). A "comunicação denotativa tal como existe em um nível humano só é possível depois da evolução de um conjunto complexo de regras metalinguísticas (mas não verbalizadas) que governam como palavras e sentenças devem se relacionar a objetos e eventos", i.e., viria depois dessa experiência lúdica e pré-verbal com a linguagem, experiência que, na medida em que suspende metalinguisticamente a denotação (que aqui estamos tomando, argumentativamente e de forma talvez imprecisa, como sinônimo de referenciação), abrindo a referência para aquilo que ela não é, pode ser caracterizada, nas

\footnotetext{
${ }^{7}$ Apoio-me, no que se segue, na leitura que Juliana Fausto (2017) faz de Bateson em sua magnífica tese.
} 
palavras do próprio Bateson (2000, p. 182), como "ficcional": "[n]ão apenas os animais que brincam não querem dizer exatamente o que estão dizendo, como também usualmente estão comunicando sobre algo que não existe". A literatura não nos levaria (verbalmente) a essa outra experiência (pré-verbal) da linguagem, e, portanto, da subjetividade, em que ela está em jogo, em que ela é um jogo?

\section{Ele, a primeira pessoa}

Eu é um outro

Rimbaud

A suspensão originária da referência se deixa ver também naquele que, segundo Winnicott (1975, p. 134), é o "primeiro" objeto, o "objeto transicional", "a primeira possessão não-eu" - e ressalto a ambiguidade não intencional da tradução, na medida em que usualmente o termo "possessão" tem menos o sentido de apossamento de um objeto que o de tomar a subjetividade de alguém. Os "naninhas" (para tomar uma das suas formas mais comuns) na teoria winnicottiana que pretendo abordar não psicanaliticamente, mas tomando-os enquanto uma "estrutura ontológica", como Lacan fez com o estádio do espelho, serviriam como transição de um estado de fusão com a mãe (e, a bem dizer, com o mundo em geral, pois nesse estágio tudo é o bebê para o bebê) para outro em que interioridade e exterioridade, subjetividade e objetividade, identidade e alteridade, aparecem separados. Nem dentro nem fora, nem um objeto externo nem um objeto interno, nem a mãe nem um pedaço de pano, entre ambos, o objeto transicional é um meio pelo qual o bebê, ao mesmo tempo, se distancia e se liga com a mãe, constituindo a ambos. Tal constituição conjunta e recíproca de si mesmo e do mundo, e das relações entre ambos, seria, assim, uma ferramenta ontológica pela qual ele inventa a si mesmo e um mundo. "Invenção", pois se trata tanto de criação quanto de encontro (in-venire):

o bebê cria o objeto, mas o objeto ali estava, à espera de ser criado e de se tornar um objeto catexizado. Tentei chamar a atenção para esse aspecto dos fenômenos transicionais, reivindicando que, pelas regras do jogo, todos sabemos que nunca desafiaremos o bebê a dar uma resposta à pergunta: você o criou ou o encontrou? (Winnicott, 1975, p. 124-125).

Estando na "zona intermediária", o objeto transicional possui um estatuto paradoxal, pelo qual ele é e não é, ou é duas coisas ao mesmo tempo: "O fato de ele não ser o seio (ou a mãe), embora real", diz Winnicott (1975, p. 19), "é tão importante quanto o fato de representar o seio (ou a mãe)". Operando do mesmo modo que a suspensão da referência que caracteriza a literatura e o jogo animal, como vimos, constituindo uma contradição que parece estar na raiz de toda operação artística (por exemplo: quando encena, um ator é e não é ao mesmo tempo ele mesmo e seu personagem), não é um acaso que o espaço transicional, chamado também de potencial e espaço da experiência, persista para Winnicott durante toda a vida naquelas atividades cobertas pelo espectro semântico de play, incluindo a arte e a cultura em geral - o jogo, a brincadeira, a atuação, a literatura. A partir disso, seguidamente, a teoria literária de Iser a Zumthor (ver Rudnytsky, 1993) invocou a transicionalidade para caracterizar a experiência literária, o que também quero fazer, mas com alguns desenvolvimentos ou clarificações que julgo essenciais.

Em primeiro lugar, arriscaria dizer que o objeto transicional não se situa apenas entre o dentro e o fora, mas também entre o eu e o outro, no caso específico, a criança e a mãe, porque o objeto é transicional aos dois, uma forma também da mãe conseguir se separar do bebê: o naninha não é a mãe apenas para a criança, mas também para a própria mãe, que se deixa levar, ser este objeto (até para a sua saúde e a do bebê). Isso implica dizer que ele é a objetivação ou tangibilização de uma relação, tanto inter-subjetiva (eu-outro) quanto com o mundo (dentro-fora), um entre-sujeito equívoco, a terceira pessoa.

Segundo, como consequência, o objeto transicional pode ser descrito como uma dupla objetivação: por um lado, do bebê e seus afetos no mundo; por outro, da mãe no objeto - um (ponto de des-)encontro entre dois sujeitos oblíquos. Por isso, enquanto "possessão não-eu", ele 
é, também, para tomar emprestado uma expressão de Tarde (2007, p. 112), uma "possessão recíproca", e em vários sentidos: mãe e bebê possuem o objeto (o objeto é deles); o objeto é possuído subjetivamente pela mãe e pelo bebê; por meio dele, bebê e mãe possuem objetivamente um ao outro; e bebê e mãe são possuídos subjetivamente um pelo outro.

Terceiro: o objeto transicional é também um sujeito transicional, na medida em que ele é animado, possui subjetividade: o bebê e os adultos ao seu redor têm de obedecer às suas vontades - estão sujeitos a ele, são seus objetos. Que os adultos só vejamos aí projeções do bebê e não uma forma de subjetividade do objeto transicional operando diz mais de nós e do que concebemos como sujeito do que do bebê e seu naninha: e o que estou sugerindo, na esteira do próprio Winnicott, que insiste na necessidade de adotar o ponto de vista do bebê para entender o que está em jogo, é levar a sério essa subjetividade, essa prosopopeia (o movimento de subjetivação poética: fazer pessoas). Ou seja, ao invés de ver aí só um jogo, deveríamos tentar entender a outra concepção de jogo em jogo.

Por fim, como corolário disso tudo, poderíamos dizer que, se os objetos transicionais são uma forma de inventar o sujeito e o mundo, se antes deles não há objetos externos, mas por isso mesmo tampouco sujeitos, então o primeiro objeto é um sujeito (transicional), assim como o primeiro sujeito é um objeto (transicional), em suma, que o primeiro sujeito não é o próprio eu (bebê). Entre o sujeito e o objeto, o primeiro sujeito é o sujeito oblíquo, o sujeito tomado como objeto, o objeto tomado como sujeito: a primeira experiência da subjetividade é a da obliquação. Para dizer eu, é primeiro preciso obliquar-se, é preciso ser ele. Antes do sujeito transcendental, há o sujeito transicional que suspende a transcendentalidade para dar lugar a um campo de imanência, de transicionalidade, onde aquela se constitui e constantemente se reconstitui (Catren, 2017). O a priori vem sempre a posteriori.

\section{How to make (up) people (playing) with words?}

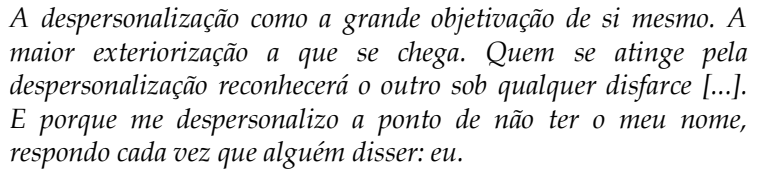

A despersonalização como a grande objetivação de si mesmo. A maior exteriorização a que se chega. Quem se atinge pela despersonalização reconhecerá o outro sob qualquer disfarce [...]. E porque me despersonalizo a ponto de não ter o meu nome, respondo cada vez que alguém disser: eu.

Clarice Lispector, A paixão segundo G.H.

Do que dissemos, salta aos olhos (ao menos, aos meus) a analogia entre os objetos (sujeitos) transicionais e os personagens literários, esses "egos experimentais" ou "imaginários". Dotados de certa consistência material "externa" (o livro), ao mesmo tempo são animados por sujeitos, ou melhor, por uma relação de sujeitos e seus contextos, seus espaço-tempos, seus mundos, dentre os quais, o autor e o leitor, mas não só, pois inúmeras leituras em tempos e locais distintos vão aderindo ao ou ressoando o objeto de ontologia instável que é o texto literário (Dimock, 1997). Por isso, o espaço transicional não é um espaço em sentido metafórico, mas uma espacialidade de pleno direito, uma heterotopologia, para jogar com o termo de Foucault, em que contextos, mundos, se encontram, chocam ou equivocam: a continuidade espaçotemporal, como veremos, dá lugar à contiguidade de lugares e tempos, no qual estes se rearranjam, se refazem a partir do seu encontro com o presente. É nele que nos perdemos a cada vez que nos obliquamos - apenas para nos reencontrarmos e ao mundo transformados: "doing things takes time. Playing is doing" (Winnicott, 1975, p. 29, grifo nosso).

Mas se a transicionalidade é, de fato, uma estrutura ontológica que persiste por toda a vida, pela qual o sujeito (re)inventa a si mesmo e ao mundo e os objetos, suas posições e relações, a (re)constituição tanto da separação quanto da articulação entre dentro e fora, então, na experiência literária, não são apenas os personagens ou o texto (o objeto) que são transicionais, mas também os sujeitos que os animam, como o autor e - o que nos interessa mais aqui - o leitor, os quais não estão totalmente fora do espaço transicional quando escrevem ou leem, mas 
também dentro dele: sujeitos(-objetos) transicionais. Que a transicionalidade não diga respeito só aos objetos, mas à relação sujeito-objeto, resta claro, como vimos, já na teoria winnicottiana. Assim, se uma figura da transicionalidade é o cordão que serve para, ao mesmo tempo, unir e separar, ou seja, relacionar, o seu correlato no sujeito seria uma "parte da organização do ego [...] que não é um ego corporal", a "capacidade de relacionamento do ego (ego-relatedness), no local em que se pode dizer que a continuidade está cedendo lugar à contiguidade" (Winnicott, 1975, p. 140, grifos do autor). Dito de outro modo: a transicionalidade constitutiva do sujeito, seu playground, permanece nele sob a forma de seus furos, seus poros, por meio dos quais ele se compara (1975, p. 178) com outros e seus mundos que "retroalimentam a substância outra-queeu no sujeito" (1975, p. 131, grifo nosso, tradução modificada). Isso implica que, para caracterizar a transicionalidade, não basta postular que, nela, a referenciação "externa" está suspensa: também a continuidade do sujeito, seu fechamento, dá lugar à contiguidade com os outros e seus mundos. E aqui, a experiência literária pode iluminar a e ser iluminada pela transicionalidade, pois, nela, a contradição se torna uma contradiçcão. Quando digo "eu" ao ler Quixote dizendo eu, referente e referido, sujeito e objeto não coincidem, mas se equivocam - eu não sou o único eu a quem me refiro. Mas a quem mais me refiro, senão justamente ao "ele", o terceiro excluído da interlocução? Quem fala é a terceira pessoa, o entre-sujeito que se tangibiliza e anima pela nossa obliquação; ou melhor, nos fala, através de nós e sobre nós afinal, é nossa uma das muitas vozes (sopros) que o anima.

A experiência literária constitui, assim, um ponto-limite em que a enunciação se torna algo outro, ao se inverter ou se dobrar completamente sobre si mesma: os sujeitos se tornam objetos e viceversa. Colocando em xeque a preponderância das duas primeiras (e, para Benveniste, únicas) pessoas, ela faz aparecer uma terceira pessoa dotada da mesma prerrogativa de subjetividade das demais: na literatura, "a eu-originidade (ou subjetividade) de uma terceira pessoa [ou seja, um objeto] pode ser apresentada na terceira pessoa" (Hamburger 2013, p. 58). Se Benveniste (1995, p. 283) dizia que "distintiva da 'terceira pessoa' é a propriedade: [...] de não ser jamais reflexiva da instância de discurso [...]; [e] de não ser compatível com o paradigma dos termos referenciais como aqui, agora, etc.", Hamburger demonstrou que na literatura que chama de "épica" (numa classificação contestável que não cabe aqui abordar), os dêiticos, quebrando essas regras, combinamse com o uso da terceira pessoa, sendo esta (na figura dos personagens) que serve de ponto zero (euorigo) da referencialidade espaço-temporal, fazendo, com isso, da não-pessoa a instância reflexiva do discurso. Se, a princípio, só temos acesso à subjetividade de alguém por meio dela mesma, na primeira pessoa, e que, enquanto não fala, é objeto da nossa enunciação ou eco do nosso "eu" (um "tu" a quem nos dirigimos), a literatura aparece como "o único lugar linguístico ou epistemológico onde as pessoas não são tratadas, ou apenas tratadas como objetos, mas também como sujeitos, ou seja, é onde a subjetividade de uma terceira pessoa pode ser representada como de uma terceira pessoa": "[a] ficcionalização das pessoas narradas significa justamente isso: devem ser descritas não como objetos, mas sim como sujeitos, isto é, como eu-origines" (Hamburger, 2013, p. 98, 97).

Mas, para que ele fale, para que a não-pessoa se faça pessoa, é necessário a experiência da leitura, é preciso que um eu ocupe a posição do "ego experimental". E é aqui, nesse gesto aparentemente banal e tão corriqueiro, que as coisas se complicam. Pois o personagem não constitui uma posição linguística vazia a ser plenamente ocupada por nós, como cremos fazer quando dizemos "eu" cotidianamente: o "ego imaginário" possui, como vimos, certos contornos dados pelo texto, pelas camadas de leitura que se sedimentaram junto a ele, pelo contexto presente do tempo da leitura, etc. Não podemos fazer dele o que bem entendermos. Por outro lado, tais contornos também não o constituem como uma posição plenamente ocupada, a qual só caberia ao leitor emular passivamente: antes, é preciso a nossa subjetividade (e nosso mundo) para co-animar esse entre-sujeito equívoco em conjunto com os outros sujeitos que dão corpo ao feixe de relações que chamamos de texto. A ocupação em jogo, portanto, conjuga paradoxalmente as duas modalidades, uma ocupação parcial que é simultaneamente participante e participativa, que também nos ocupa: o aporte de nossa voz (singular) dá voz ao conjunto do coro (múltiplo) de que ela participa. Fazer ele falar é falar tanto vicária quanto propriamente, colocar-se tanto passivamente (enquanto ventríloquo) como a relação que o 
constitui (ser o outro), quanto ativamente (contribuindo com a voz própria), como uma parte dele (ser a si mesmo). O processo dinâmico da leitura revela isso pelo jogo entre identificação e estranhamento: um exercício instável e metamórfico em que temos de aportar (mesmo de modo inconsciente), como parte da relação, a nossa perspectiva e mundo para dar sentido e consistência (co-animar) aos egos experimentais, mas que também nos obriga, pelo desenrolar do texto, a constantemente rever isso que de nosso estamos aportando, fazendo-nos ouvir tanto como nossa voz emite acordes dissonantes, e, igualmente, quanto o coro não em uníssono, mas distorcido, em suma, dando a ver aquilo que no ego imaginário estamos projetando, dando-nos a ver segundo os olhos do outro (a relação), em um movimento pelo qual o modo da nossa ocupação vai se (e nos) modificando. Assim, por um lado, o leitor empresta seu corpo e sua subjetividade na leitura para que o personagem (ele) diga "eu", se subjetive, entrando no texto: coloca-se como um objeto (a não-pessoa) que é um sujeito (a terceira pessoa), sujeito para o qual os demais (incluindo, portanto, logicamente, o leitor) são objetos (identificar-se com o personagem é adotar o seu ponto de vista, a sua perspectiva de mundo, ou seja, ver-se com os seus olhos). Por outro lado, o leitor não deixa de manter a sua posição subjetiva e, de fora, acompanhar e conduzir esse movimento, vendo o personagem como uma terceira pessoa, um objeto de seu mundo. Na experiência literária, esses dois lados da moeda aparecem ao mesmo tempo em um movimento giratório vertiginoso - paralaxe.

Então, de fato, há, quando se diz "eu" na experiência literária, uma "suspensão da descrença", em que o acento deve recair sobre a suspensão: por meio dela, se dá a identificação com o personagem ou texto; mas há também uma suspensão da crença, pela qual há o estranhamento em relação a eles; na conjugação dessas duas suspensões, entre a identificação e o estranhamento, na terceira margem transicional se estabelece a equivocidade da experiência literária. Pois a graça da brincadeira não reside simplesmente em estar dentro do jogo, mas em entrar e sair, estar ao mesmo tempo dentro e fora, o que fica patente quando observamos uma criança brincar ou brincamos com ela: o jogo em si é essa mudança constante de posições, é ocupar uma terceira margem entre a "realidade" e seu outro.

Portanto, precisaríamos dizer que a referencialidade que se suspende na experiência literária diz respeito também ao próprio referir-se do eu a si mesmo quando se diz eu. Suspensão da coincidência ou univocidade referenciais, que não deve ser confundida com um discurso citado, pois, em primeiro lugar, insistamos, o personagem (e o texto) é constituído por um feixe de relações no qual se inclui o próprio leitor na medida em que este participa da animação do ego experimental. E, em segundo, porque a suspensão é dupla, no sentido de que, por um lado, o eu-leitor não se refere só a si quando diz "eu" na leitura, mas também ao personagem, assim como, por outro, a referência do personagem a si mesmo quando diz "eu" está suspensa, porque ele também está falando do leitor, da gente. Na experiência literária, não só falamos, como somos falados. Se não paramos de pensar em nós mesmos, na nossa vida, no nosso contexto quando lemos literatura, não é só porque nos comparamos aos personagens (reflexividade), às situações ou, de modo mais geral, ao texto; antes, também estamos sendo comparados por eles (obliquação, ficcionalização).

E tudo se torna ainda mais complexo se levarmos em consideração o óbvio, a saber, que nunca há apenas um "eu", um único ego experimental num texto literário, que é composto por uma multiplicidade deles, pois, a rigor, tudo diz eu, tudo fala, tudo faz sentido num texto literário, sendo o seu ponto de co-incidência, ou melhor, de equivocação, a sua referência, o seu ele, o leitor: um texto é feito de escrituras múltiplas, oriundas de várias culturas e que entram umas com as outras em diálogo, em paródia, em contestação: mas há um lugar onde essa multiplicidade se reúne, e esse lugar não é o autor, como se disse até o presente, é o leitor: [...] o leitor é um homem sem história, sem biografia, sem psicologia: ele é apenas esse alguém que mantém reunidos em um único campo todos os traços de que é constituído o escrito (Barthes, 2004, p. 65).

Ao me obliquar e ler um texto literário, entro em uma zona de muitos eles (entre os quais eu mesmo) que, dizendo eu, falam de mim, constituem (objetivam e subjetivam) a mim como entre-sujeito equívoco. 


\section{A gente, voz média}

Como demonstrou Wolfgang Iser, não há um ponto de vista fixo do leitor dentro de um texto literário - nem tampouco ele pode ocupar uma posição totalmente fora dele (é preciso suspender a referência a si). O que há são múltiplas perspectivas (dos personagens, do enredo, do narrador, do leitor fictício a quem esse se dirige) que se cruzam, se chocam, se alternam. $\mathrm{O}$ ponto de vista do leitor, enquanto "não-dito" do texto, consistiria na interação e articulação, feitas e refeitas no gesto de leitura, desses pontos de vista (incluindo o seu próprio, suspenso), cujo movimento e variação faz com que constantemente tenhamos que rever nossa perspectiva, estranhando o que projetamos no texto ao ocupar suas posições, e mesmo estranhando tal ocupação: "a leitura mostra quão pouco o sujeito é algo dado", de modo que "a literatura oferece a oportunidade de formularmo-nos a nós mesmos, formulando o não-dito" (Iser, 1999, p. 93).

O que o texto literário apresenta, assim, é uma zona pré-agenciada da enunciação, em que as posições estão encavalgadas e precisam ser agenciadas - ao mesmo tempo de dentro e de fora dele; ou seja, cujo agenciamento está, de origem e por natureza, incompleto, necessitando para isso do leitor. Todavia, produzi-lo não é obra individual, não é tarefa de um sujeito. Como estamos vendo, na experiência literária, a enunciação, o dizer "eu", não consiste no "ato individual de utilização" que coloca "em funcionamento a língua", ou no "ato individual de apropriação da língua", pois, aqui, agenciar implica ser agenciado: ao ordenar as posições e relações, é a minha própria posição e relação com as demais que varia. A voz verbal da obliquação é a voz média, que não deve ser confundida com a reflexividade, já que consiste em uma via de mão dupla entre sujeito e objeto, agente e paciente: "no caso médio, [...], ao agir, o sujeito afetase a si mesmo, permanece sempre no interior do processo" (Barthes, 2004, p. 22). Na experiência literária, usar a linguagem é ser usado por ela, usar-se na e pela linguagem; apropriar a língua é ser apropriado por ela e pelos múltiplos sujeitos que a formam - a(-)propriar-se. ${ }^{8}$

$\mathrm{O}$ ato da leitura de Iser converte-se, assim, em nosso vocabulário, em um agir-se na/pela leitura, comportando dois vetores: de um lado, somos agenciados pelo texto, nos tornamos agentes do texto, dando voz aos múltiplos "eus" (entre os quais nós mesmos), posições, contextos, que constituem o texto, subjetivando-os, conferindo-lhes agência através de e em nós; de outro - e essa operação é o que chamamos de dar sentido a um texto, ou seja, dispor as suas veredas, construir sua orientação -, nós arranjamos as relações entre tais "eus", posições, contextos, agenciamo-nos, os dispomos em um sentido e, por meio disso, somos redispostos em relação a esse agenciamento, à nossa participação nele, dentro dele. Falando e sendo falado, o leitor, nós leitores precisamos fazer com que o texto nos faça sentido, movimentar esse arranjo e nos movimentarmos por ele. Dizer "eu" na experiência literária consiste, então, em subjetivar uma inter-subjetividade da qual se faz parte, ou seja, não se limita a ocupar uma posição determinada pelo agenciamento coletivo da enunciação, mas fazer a experiência do próprio

\footnotetext{
${ }^{8}$ Roland Barthes (2004, p. 22, 39), que insistia na voz média como marca do "escrever moderno: escrever é hoje fazer-se o centro do processo de palavra, é efetuar a escritura afetando-se a si próprio, é fazer coincidir a ação e o afeto, é deixar o escritor no interior da escritura", parece apontar para ela também quando afirma que "a leitura é condutora do Desejo de escrever": "desejamos o desejo que o autor teve do leitor enquanto escrevia, desejamos o ame-me que está em toda escritura”. A voz média da experiência literária, encavalgando sujeito e objeto da escritura, sobrepõe também escrita e leitura, atividade e passividade, numa corrente de imantação semelhante à descrita por Platão em Íon: escrever-se o texto (escrever a si, ser escrito, o texto se escrever, nos escrever) ou ler-se o texto (ler a si, ser lido, o texto se ler, nos ler). Tal encavalgamento posicional da obliquação, sua voz média, se deixa ver, assim, nitidamente na leitura individual, na medida em que nela a voz (mesmo que interna) de quem está lendo, quem está contando, é do mesmo sujeito que ouve, recebe - situação estranha em que o sujeito conta para si mesmo e vivencia uma estória de alguém que talvez não tenha existido, redigida por outro, cuja voz ele (o leitor) ecoa, e que, ademais, parece lhe dizer respeito. Ao ler um romance, o leitor não está apenas recebendo, mas como que escrevendo, embora não saiba o que escreve, numa espécie de escrita automática. Daí a similaridade formal entre literatura e sonho: no sonho, contamos para nós mesmos uma história, a vivenciamos, mas não conhecemos o que vai acontecer, ou mesmo que saibamos, não podemos modificar. Então, se escrever (literatura) é, como aponta Clarice, muitas vezes "lembrar-se do que nunca existiu", então talvez possamos dizer que ler (literatura) é, tantas outras, lembrar-se do que nunca se escreveu.
} 
agenciamento em que temos lugar. Ou, por outra, dizer "eu" na obliquação consiste em dizer "a gente", pronome que no português brasileiro comporta em si o encavalgamento posicionalpronominal que estamos mapeando: substituto da primeira pessoa do plural, mas conjugado na terceira do singular (não-pessoa), pode ser usado tanto como sujeito indeterminado quanto no lugar do "nós", seja inclusivo ou exclusivo, bem como uma forma de generalização do "eu". Na obliquação, o "eu", convertido em a gente, é em si mesmo um agenciamento coletivo da enunciação - o arranjo sempre precário, que está sempre se (re)fazendo, de muitos "eus", uma experiência posicional-pronominal não mais da individualidade, mas da agência subjetiva múltipla. A tarefa do leitor é fazer desse a gente um a-gente poético, e, assim, fazer-se "eu", inventar a si, ou, para usar as palavras de Winnicott, dar lugar à amorfia necessária para se criar.

\section{Ocupação, ou do outro}

A-gente é quem imita, isto é, difere de si mesmo, vira outro.

Rondinelly Medeiros

Que a experiência da obliquação, da transicionalidade em seu modo literário, não seja inócua e comporte seus perigos pode ser atestado pela preocupação de Platão com a mudança das ocupações de cada um na polis que a mudança na ocupação das posições enunciativas pela literatura poderia ocasionar. Como se sabe, a crítica platônica à mimese diz respeito, no Livro III da República, aos modos de enunciação, às pessoas do discurso poético. Trata-se, ali, de diferenciar valorativamente relato (diegese) e imitação (mímese de diálogos), narração simples, em terceira pessoa, dos atos, que mantém uma distância saudável dos personagens, e "reprodução", em primeira pessoa, "dos discursos pronunciados" (393b) por eles. A mimese em jogo nessa passagem se restringe ao sentido estrito, aos momentos em que o poeta "fala sob o nome de outrem", tornando "na medida do possível a sua elocução semelhante à da personagem cujo discurso ele nos anuncia" (393c), e, com isso, "tornando-se semelhante a outrem com respeito à voz e ao aspecto", ocupando a posição enunciativa de outro, ou melhor: sendo ocupado, no próprio corpo, por outra voz. A desvalorização da mimese se justifica com o argumento de que a prática da imitação é contagiante e viciante, ou seja, de que os ouvintes não apenas imitarão aquilo que o poeta imitar, mas tomarão gosto pela imitação em si, pois "se se persevera em cultivá-la [a imitação] desde a infância, fixa-se nos hábitos e converte-se numa (segunda) natureza do corpo, da voz e até da inteligência" (395d, parênteses adicionados). Mas como essa espécie de pulsão de mimese não pode ser eliminada, a solução é controlar e dirigi-la, traçando-se uma fronteira entre o que deve e o que não deve ser imitado, fronteira na qual se coloca o problema de gênero: a efeminação (que reaparecerá no Livro X), ou seja, a imitação de "uma mulher jovem ou velha, seja no ato de injuriar o marido, ou quando se ponha a rivalizar com os deuses, para gabar-se de sua felicidade; ou [...] apaixonada ou nas dores do parto" (395d-e), constitui o ponto de corte, princípio de uma série tendencialmente infinita de desvios, metonímia da má imitação, série que incluirá "os indivíduos maus e covardes" (395e), "a linguagem e a conduta dos loucos" (396a), e os animais e seres inanimados ("o relincho dos cavalos, o mugido dos touros, o murmúrio dos rios, o fragor do mar, o trovão e todos os ruídos do mesmo gênero" - 396b), pois também a prosopopeia comporta seus perigos.

Dito de outro modo, o impulso mimético deve ser convertido em imitação de si, ou melhor, do modelo da posição que cabe a cada um na polis. Além disso, a própria divisão hierárquica, a própria manutenção dos lugares separados (a cada um uma única posição) deve ter lugar na forma poética, a qual, portanto, não pode comportar a multiplicidade de posições enunciativas destoantes. Por isso, a poesia que mimetiza tanto diálogos elevados quanto baixos, que imita igualmente homens bons e indignos "não convém ao nosso governo, porque, em nosso meio, não há homem duplo nem múltiplo e cada um faz somente uma coisa" (397d-e): "em nossa cidade se encontrará o sapateiro sapateiro, e não piloto ao mesmo tempo que sapateiro, o lavrador lavrador, e não juiz ao mesmo tempo que lavrador, o guerreiro guerreiro e não comerciante ao mesmo tempo que guerreiro" (397e). 
A grande ameaça da arte para Platão era, assim, que o modo poético saísse do palco e tomasse a polis de assalto. No seu diálogo sobre as Leis, essa invasão foi inclusive descrita como já tendo acontecido. Ali, o "declínio" ateniense (a democracia) aparece ligado ao que ele chamou de "teatrocracia" (701a), o domínio do auditório: os poetas, ignorando a medida, o "padrão de correção" (700d), e substituindo esse critério pelo prazer do ouvinte, "seja ele um bom ou mau homem" (700d), começaram a misturar os gêneros e as formas, acabando com a diferença entre a boa (justa) e a má (ilegal) música, ao que se seguiu, consequentemente, a intromissão cada vez maior do público nas encenações, disposto a julgar por conta própria e desprezando as leis musicais o que ouviam, sem a mediação "da opinião de homens melhores" (701b), e prepotente ao ponto de levar esta intromissão à política, "recusando ser súdito dos governantes" (701b), ao domínio familiar, e, por fim, ao sobrenatural, com a perda de respeito nos juramentos e nas divindades. Para reverter a situação, Platão sugere, nesse diálogo tardio, a censura prévia, por juízes nomeados como legisladores da música e supervisores da educação, já que a "tribo dos poetas" (poietôn génos) seria incapaz de discernir o que é bom do que não é $(801 \mathrm{~b}-\mathrm{c})$. Do mesmo modo, qualquer alteração nos jogos infantis seria proibida: inovando neles, as crianças iriam querer, quando adultas, inovar nas leis e instituições, buscando um modo de vida distinto (állon Bíon) daqueles dos pais (798c) - a alteração.

Ou seja, o jogo poético coloca em jogo, em questão, a posição de cada um, a relação de cada sujeito com os demais e com o Estado, mas também a própria fala, o próprio dizer, o próprio corpo e voz, em suma, a própria subjetividade: essa fala que imito ou que me move é própria?, esse corpo e essa voz são minhas, sou eu? Mas se posso mimetizar incessantemente a elocução ou enunciação alheia, a ponto da mimese se tornar uma (segunda) natureza, então quem sou esse cujo mais próprio é mimetizar? Sou uno ou duplo ou múltiplo?

O problema consiste, portanto, em que o sujeito difira de si na experiência literária. Nesse sentido, pensando que a "esfera original da mímesis - ou melhor, de mimos e miméisthai - era a imitação de seres animados, animais e humanos, pelo corpo e pela voz" (Else apud Lima, 1980, p. 33), e que a etimologia de play remete a uma raiz que indica ocupar-se de algo, engajar-se em uma atividade, implicar-se em uma ação, ${ }^{9}$ poderíamos pensar a obliquação como alterocupar-se, na medida em que nessa experiência a ocupação de si em alguma coisa envolve um outrar-se. Em uma bela monografia, Yuri Kulisky demonstrou como esse movimento e suas consequências se dá na poética celaniana, num raciocínio que podemos estender à experiência literária de um modo geral. "[O] poema é ocupável", diz Celan, ou seja, não ocupado de uma vez por todas, mas sempre aberto à ocupação de cada leitura, a cada vez, sem jamais se fechar definitivamente. A ocupabilidade perene faz com que o tempo de um poema seja sempre o aqui e agora da leitura, que não se confunde com o tempo presente, pois que implica, justamente, que nos percamos do nosso tempo - o seu tempo se dá quando nos ocupamos dele, quando ele nos ocupa. Trata-se de uma via de mão dupla, que Celan (1999, p. 179) também chama de atenção: por um lado, a "atenção que o poema tenta dedicar a todos que encontra", e, por outro, "A atenção do leitor: uma devoção ao poema". ${ }^{10}$ É nesse movimento, de ocupação (atenção) recíproca do leitor pelo poema e do poema pelo leitor que emerge uma outra cena da enunciação, a interlocução própria da experiência literária: “O poema torna-se [...] diálogo. Somente no espaço desse diálogo se constitui o solicitado, reúne-se em torno do Eu solicitado e nomeado. Mas a esse

\footnotetext{
${ }^{9}$ Veja-se, além disso, essa passagem de Huizinga (2001, p. 45-46): "Do ponto de vista formal, há uma correspondência total e indubitável entre o inglês arcaico plegan e o saxão antigo (continental) plegan, o alto alemão arcaico pflegan e o frisão antigo plega. Todas estas palavras, das quais derivam diretamente, em alemão, pflegen e, em holandês, plegen, possuem, todavia, um sentido abstrato que não é o do jogo. Os significados mais antigos são: 'dar garantia de, correr um risco, expor-se a um perigo por alguém ou alguma coisa'. Seguem-se 'comprometer-se ou vincular-se (sich verpflichten), assistir a, tomar conta de (verpflegen)'. [...] Quem poderia negar que todos estes conceitos - desafio, perigo, competição etc. - estão muito próximos do domínio lúdico? Jogo e perigo, risco, sorte, temeridade - em todos estes casos trata-se do mesmo campo de ação, em que alguma coisa está "em jogo"”.

${ }^{10}$ A segunda citação é extraída da dissertação de Hugo Simões. No original, lê-se: Die Aufmerksamkeit des Lesers: Eine Zuwendung zum Gedicht. Não se deve, porém, tomar isso como semelhança de concentração, pois em arte a atenção não é o contrário da distração, mas o movimento de tender a algo outro de si, descontrair, (o contrário de contrair-se sobre si). Assim, aponta Simões (2017, p. 26), Zuwendung (devoção) "pode ser também atenção": "a diferença está na etimologia da palavra: zu + Wendung, uma viração (Wendung) em direção a (zu). A atenção do leitor exige uma volta, um movimento, uma viração em direção ao poema: exige que o leitor se movimente, sinta seu corpo ser atraído em direção ao poema que busca incessantemente um $D u$ ".
} 
momento o solicitado, e como que tornado Tu pela nomeação, traz consigo seu Ser-Outro. Ainda no Aqui e no Agora do poema [...], ainda nessa imediatez e proximidade ele deixa dialogar o que é mais próprio deles, desse Outro: o seu tempo" (Celan, 1999, p. 179). Como comenta Kulisky (2017, p. 6, grifo nosso), "o poema é, portanto, um modo de inscrever, no tempo da leitura, o tempo do Outro, deste Outro que, entre Eu e Tu, como resto do revezamento pronominal que é um gesto frequente na poesia celaniana" e característica da experiência literária, se faz em nós. O tempo da leitura é, desse modo, o tempo do outro, um tempo outro inscrito em cada presente, um tempo alterado, o tempo transicional, da alteração. Pois o outro, aqui, não é uma substância ou uma posição enunciativa ou textual previamente dada ("tu", "ele", um personagem), mas o resto que se produz na gente pela ocupação e rearranjo das posições do texto, o resto que a gente produz no movimento entre as e das posições. A poiesis da experiência literária faz resto - e seu nome é outro. Mais: essa alteridade que resta em nós como produto da obliquação nos altera: o outrar-se não consiste, assim, apenas em "ser os outros para conhecer o que não era eu" (Lispector, 1999, p. 385), identificar-se ao ego experimental, mas no efeito da trans-posicionalidade literária, da transposição (travessia e atravessamento de posições) que faz o sujeito estranhar a si, que faz emergir em si uma alteridade que nos altera, que produz na gente uma alteração, que é esta alteração do sujeito. Diante dessa alteridade, o sujeito se refaz, a gente se refaz na experiência literária, uma modalidade da "experiência maior" de que falava Clarice Lispector: a de "ser o outro dos outros: e o outro dos outros era eu" (Lispector, 1999, p. 385) - o eu como alteração produzida pela alteridade. Eduardo Viveiros de Castro me sugeriu chamar isso de egolocação (em referência à ecolocação dos morcegos), ao que eu responderia que ela se dá por meio de uma ecolocução, uma enunciação por ecos dos outros que nos dizem eu.

É como se a transicionalidade da experiência literária fosse uma contrafação de si (conjugando tanto o sentido de adulteração, falsificação, quanto o de destruição, ou seja, tomando-a como suspensão de si) que desse acesso a um espaço de (re)fazenda do sujeito e do mundo e de suas relações. Daí a sensação comum de que um mundo está se fazendo quando lemos um texto literário, aquela "experiência primeira - plena - do real" (Castro et al., 1959, p. 11) de que falava o Manifesto neoconcreto. Daí também a sensação de que saímos transformados da leitura, embora nada mude "de fato", "objetivamente" ou mesmo "subjetivamente" em nossa vida, pois o que mudou não foram propriedades objetivas ou subjetivas, mas todo o campo da subjetividade e da objetividade, suas posições, suas constituições, suas relações e configurações.

\section{Pessoa, heterônimo}

O homem é, quando muito, o diferencial de seus papéis, que podem se inverter e modificar mutuamente.

Wolfgang Iser

O exemplo mais conhecido do que estamos chamando de obliquação é a heteronímia de Pessoa, cujo surgimento ele remonta a um fenômeno transicional, os chamados amigos imaginários, tão antigos quanto a sua própria subjetividade:

Desde criança, tive a tendência para criar em meu torno um mundo fictício, de me cercar de amigos e conhecidos que nunca existiram. [...] Desde que me conheço como sendo aquilo a que chamo eu, me lembro de precisar mentalmente, em figura, movimentos, carácter e história, várias figuras irreais que eram para mim tão visíveis e minhas como as coisas daquilo a que chamamos, porventura abusivamente, a vida real. Esta tendência, que me vem desde que me lembro de ser um eu, tem-me acompanhado sempre, mudando um pouco o tipo de música com que me encanta, mas não alterando nunca a sua maneira de encantar (Pessoa, 1935, s.p.).

No "outrar-se" de Pessoa, à despersonalização de si corresponde a subjetivação de outro, ao que se segue, como resposta, uma nova subjetivação de si, mas de um eu transformado pelo 
aparecimento do heterônimo, e reconstituído pela relação com ele (o eu como outro do outro): assim, por exemplo, Chuva oblíqua "foi a reação de Fernando Pessoa contra a sua própria inexistência como Alberto Caeiro" (Pessoa, 1935, s.p.). Mas não é só isso: a experiência em jogo abarca as várias acepções que o termo "heterônimo" possui em outras línguas (acepções que Pessoa provavelmente conhecia - e, afinal, é de outras línguas que se trata), como no inglês e no francês, num campo semântico próximo ao de "equívoco": 1) uma palavra com mesma grafia, mas pronúncia e sentido diferente - a letra de Pessoa, o estilo e a orientação de seus outros; 2) uma tradução que não recobre perfeitamente a palavra traduzida - os heterônimos que não cessam de voltar e se multiplicar, por meio de uma pessoa que não dá conta deles; 3) palavra que possui sentidos contraditórios - o próprio "eu" dos heterônimos e de Pessoa; 4) palavras que não são sinônimas, mas que possuem um mesmo hiperônimo - banana e maçã em relação à fruta, Alberto Caeiro, Ricardo Reis, Álvaro de Campos em relação à Pessoa; ou Alberto Caeiro, Ricardo Reis, Álvaro de Campos, "Pessoa-ele-mesmo" (como se referia para se diferenciar dos heterônimos), em relação a Pessoa, ou em relação à pessoa. Nesse outrar-se radical, a afirmação, referente aos primeiros heterônimos, mas válido a todos, de que "não sei, bem entendido, se realmente não existiram, ou se sou eu que não existo", pois "nestas coisas, como em todas, não devemos ser dogmáticos" (Pessoa, 1935, s.p.), deve ser tomada ao pé da letra: Pessoa, o eu, a pessoa, não existe - "Sou, porém, menos real que os outros, menos coeso, menos pessoal, eminentemente influenciável por eles todos" (Pessoa, 1935, s.p.) -, sendo a diferencial das suas variações, o resultado da alteração, do resto produzido pelos seus outros, a resultante da experiência da obliquação feita pel'a-gente.

Sinto-me múltiplo. Sou como um quarto com inúmeros espelhos fantásticos que torcem para reflexões falsas uma única anterior realidade que não está em nenhuma e está em todas. Como o panteísta que se sente árvore e até flor, eu sinto-me vários seres. Sinto-me viver vidas alheias, em mim, incompletamente, como se o meu ser participasse de todos os homens, incompletamente de cada, por uma suma de não-eus sintetizados num eu postiço (Pessoa, 1935, s.p.).

A literatura é, hoje, no Ocidente, um dos poucos espaços em que ainda podemos experimentar isso - experimentar o que significa dizer eu. "Toda gente é a caricatura d'uma única pessôa que não existe. Nenhum de nós poderia figurar n'um romance realista. Somos todos falsos, inteiramente irreais" (Pessoa, 1935, s.p.).

\section{Referências}

BARTHES, Roland (2004). O rumor da lingua. São Paulo: Martins Fontes.

BATESON, Gregory (2000). Steps to an ecology of mind. Chicago: The University of Chicago Press.

BENVENISTE, Émile (1995). Problemas de linguística geral I. Campinas: Pontes.

BENVENISTE, Émile (2006). Problemas de linguística geral II. Campinas: Pontes.

BENVENISTE, Émile (2014). A língua e a escrita: Aula 8 (3 de fevereiro de 1969). In: BENVENISTE, Émile. Últimas aulas no Collège de France (1968 e 1969). São Paulo: UNESP. p. 127-133.

CASTRO, Amilcar de et al. (1959). “Manifesto neoconcreto". Jornal do Brasil, Suplemento Dominical, 21-22 mar.

CATREN, Gabriel (2017). Pleromática o las mareaciones de Elsinor. Buenos Aires: Hekht Libros.

CELAN, Paul (1999). Cristal. São Paulo: Iluminuras.

COETZEE, J. M. (2004). Elizabeth Costello: oito palestras. São Paulo: Companhia das Letras.

DELEUZE, Gilles (1997). Crítica e clínica. Rio de Janeiro: Editora 34.

DERRIDA, Jacques (2014). Essa estranha instituição chamada literatura. Belo Horizonte: Editora UFMG.

DIMOCK, Wai Chee (1997). A theory of resonance. PMLA, v. 112, n. 5, p. 1060-1071. 
ESPOSITO, Roberto (2007). Terza persona. Turim: Einaudi.

FAUSTO, Juliana (2017). A cosmopolítica dos animais. Tese (Doutorado em Filosofia) - Pontifícia Universidade Católica, Rio de Janeiro.

FELMAN, Shoshana (2003). The scandal of speaking bodies. Stanford: Stanford University Press.

FOUCAULT, Michel (2010). A hermenêutica do sujeito: curso dado no Collège de France (1981-1982). São Paulo: WMF Martins Fontes.

HAMBURGER, Käte (2013). A lógica da criação literária. São Paulo: Perspectiva.

HUIZINGA, Johan (2001). Homo ludens: o jogo como elemento da cultura. São Paulo: Perspectiva.

ISER, Wolfgang (1996). O fictício e o imaginário: perspectivas de uma antropologia literária. Rio de Janeiro: EdUERJ.

ISER, Wolfgang (1999). O ato da leitura: uma teoria do efeito estético. São Paulo: Editora 34. v. 2.

KULISKY, Yuri (2017). O Sprachgitter de Paul Celan: uma tradução. Monografia (Graduação em Letras/Alemão) - Universidade Federal do Paraná, Curitiba.

KUNDERA, Milan (2009). A arte do romance. São Paulo: Companhia das Letras.

LÉVI-STRAUSS, Claude (2003). Introdução à obra de Marcel Mauss. In: MAUSS, Marcel. Sociologia e antropologia. São Paulo: Cosac Naify.

LIMA, Luiz Costa (1980). Mímesis e modernidade. Rio de Janeiro: Graal.

LISPECTOR, Clarice (1998). Água viva. Rio de Janeiro: Rocco.

LISPECTOR, Clarice (1997). A paixão segundo G.H.: edição crítica. Madrid: ALLCA XX.

LISPECTOR, Clarice (1999). A descoberta do mundo. Rio de Janeiro: Rocco.

PESSOA, Fernando (1935/2008). Carta a Adolfo Casais Monteiro, 13 jan. Arquivo Pessoa. Lisboa. In: PESSOA, Fernando (1986). Escritos íntimos, cartas e páginas autobiográficas. Introdução, organização e notas de António Quadros. Lisboa: Publ. Europa-América. Disponível em: http://arquivopessoa.net/textos/3007. Acesso em: 22 jun. 2018.

RUDNYTSKY, Peter (Org.) (1993). Transitional objects E potential spaces: literary uses of D. W. Winnicott. Columbia: Columbia University Press.

SIMÕES, Hugo (2018). A tradução do que se cala: Paul Celan entre genocídios. Dissertação (Mestrado em Letras) - Universidade Federal do Paraná, Curitiba.

TARDE, Gabriel (2007). Monadologia e sociologia e outros ensaios. São Paulo: Cosac Naify.

THOMAS, Yan (2014). Il valore delle cose. Roma: Quodlibet.

WINNICOTT, Donald Woods (1975). O brincar e a realidade. Rio de Janeiro: Imago. 